\title{
Direct oral anticoagulants and the bleeding patient
}

\author{
Brendan Wood MDCM, Michelle Sholzberg MDCM, Alun Ackery MD MSc
}

\section{Direct oral anticoagulant agents are now routinely used for the preven- tion of stroke in nonvalvular atrial fibrillation}

Rivaroxaban, apixaban and dabigatran are now commonly used as alternatives to vitamin $\mathrm{K}$ antagonist therapy (e.g., warfarin) for patients with atrial fibrillation, and for the treatment and prevention of venous thromboembolism. Dabigatran is a direct thrombin inhibitor, whereas apixaban and rivaroxaban are direct inhibitors of factor Xa. ${ }^{1}$

Direct oral anticoagulants variably affect standard clot-based assays

All three drugs cause variable test results. This may depend on the instrument and reagents used. The results may not have linear correlation to plasma concentrations of the drugs. The activated partial thromboplastin time is more sensitive to dabigatran, but a normal result does not preclude the ongoing presence of drug and concordant bleeding risk. A normal thrombin time, however, rules out the presence of dabigatran. The prothrombin time (PT) is more sensitive to factor Xa inhibitors. Depending on the reagent used, PT may be normal even with therapeutic concentrations of factor $\mathrm{Xa}$ inhibitors. In general, the international normalized ratio is not helpful. ${ }^{3}$

CMAJ invites submissions to "Five things to know about ..." Submit manuscripts online at http://mc.manuscriptcentral. com/cmaj
Risk of bleeding with direct oral anticoagulants is lower than with vitamin $\mathrm{K}$ antagonists, but varies by site

In a meta-analysis, fewer incidents of major bleeding were reported with direct oral anticoagulants than with vitamin $\mathrm{K}$ antagonists. Specifically, fewer intracranial bleeds occurred, but the incidence of gastrointestinal bleeding was higher. ${ }^{1}$
Direct oral anticoagulants are characterized by rapid onset of action and short half-lives ${ }^{2}$

Depending on the anticoagulant, the onset of action varies from 1.5 to 4 hours, with a half-life between 5 and 17 hours (Appendix 1, available at www. cmaj.ca/lookup/suppl/doi:10.1503/cmaj .150604/-/DC1). Dabigatran tends to have a shorter onset of action and longer half-life, compared with rivaroxaban and apixaban. Drug interactions can occur with all three drugs.

Idarucizumab has recently been approved by the US Food and Drug Administration to reverse the activity of dabigatran

Idarucizumab is a humanized monoclonal antibody against dabigatran. Now in phase 3 clinical trials, andexanet is a recombinant factor $\mathrm{Xa}$ derivative designed to competitively counteract apixaban and rivaroxaban. Current strategies are largely extrapolated from bleeding in other settings (Box 1). ${ }^{4}$

\section{References}

1. Ruff CT, Giugliano RP, Braunwald E, et al. Comparison of the efficacy and safety of new oral anticoagulants with warfarin in patients with atrial fibrillation: a meta-analysis of randomised trials. Lancet 2014;383:955-62.

2. Baumann Kreuziger LM, Morton CT, Dries DJ. New anticoagulants: a concise review. $J$ Trauma Acute Care Surg. 2012;73:983-92.

3. Douxfils J, Tamigniau A, Chatelain B, et al. Measurement of non-VKA oral anticoagulants versus classic ones: the appropriate use of hemostasis assays. Thromb J 2014;12:24.

4. Siegal DM. Managing target-specific oral anticoagulant associated bleeding including an update on pharmacological reversal agents. $J$ Thromb Thrombolysis 2015;39:395-402.

\begin{tabular}{l}
$\begin{array}{l}\text { Box 1: Potential management strategies for } \\
\text { bleeding caused by direct oral anticoagulants } \\
\text { and warfarin }\end{array}$ \\
\hline Agent
\end{tabular}

Competing interests: Alun Ackery and Michelle Sholzberg received personal fees from Boehringer Ingelheim to attend a regional advisory board meeting to discuss the development of an antidote to dabigatran. No other competing interests were declared.

This article has been peer reviewed.

Affiliations: Division of Emergency Medicine (Wood, Ackery) and Division of Hematology (Sholzberg), Department of Medicine, University of Toronto; Division of Hematopathology (Sholzberg), Coagulation Laboratory and Pathobiology, Department of Laboratory Medicine, University of Toronto; and St. Michael's Hospital (Ackery, Sholzberg), Toronto, Ont.

Correspondence to: Alun Ackery, alun.ackery @ mail.utoronto.ca

CMAJ 2016. DOI:10.1503/cmaj.150604 